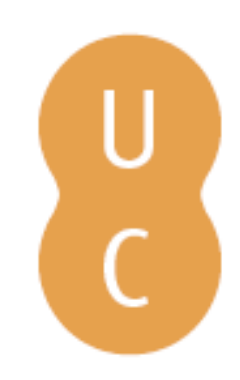

\title{
pompalina
}

\section{O logos unificador de Protágoras}

Autor(es): $\quad$ Souza, Eliane Christina de

Publicado por: Centro de Estudos Clássicos e Humanísticos; Imprensa da Universidade

URL

persistente: URI:http://hdl.handle.net/10316.2/31527

DOI: $\quad$ DOI:http://dx.doi.org/10.14195/978-989-8281-20-3_9

Accessed : $\quad$ 26-Apr-2023 11:55:37

A navegação consulta e descarregamento dos títulos inseridos nas Bibliotecas Digitais UC Digitalis, UC Pombalina e UC Impactum, pressupõem a aceitação plena e sem reservas dos Termos e Condições de Uso destas Bibliotecas Digitais, disponíveis em https://digitalis.uc.pt/pt-pt/termos.

Conforme exposto nos referidos Termos e Condições de Uso, o descarregamento de títulos de acesso restrito requer uma licença válida de autorização devendo o utilizador aceder ao(s) documento(s) a partir de um endereço de IP da instituição detentora da supramencionada licença.

Ao utilizador é apenas permitido o descarregamento para uso pessoal, pelo que o emprego do(s) título(s) descarregado(s) para outro fim, designadamente comercial, carece de autorização do respetivo autor ou editor da obra.

Na medida em que todas as obras da UC Digitalis se encontram protegidas pelo Código do Direito de Autor e Direitos Conexos e demais legislação aplicável, toda a cópia, parcial ou total, deste documento, nos casos em que é legalmente admitida, deverá conter ou fazer-se acompanhar por este aviso.

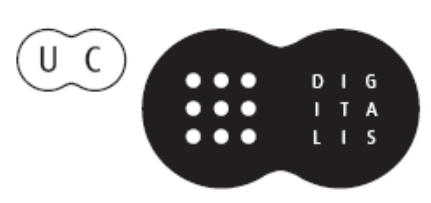




\section{Representações da Cidade Antiga}

categorias históricas e discursos filosóficos

\section{Gabriele Cornelli (Org.)}




\section{O logos Unificador de Protágoras}

Protagoras' Unifying logos

Eliane Christina de Souza ${ }^{1}$

Resumo: Do ponto de vista da retórica sofística, os atributos que tornam um argumento persuasivo são independentes do caráter científico do discurso e não há um critério universal para o julgamento e a formulação de leis. Com a falta de um critério absoluto e fixo, Protágoras propõe que a maioria escolhe o que aparece como melhor agora para a pólis. Isso coloca o homem-medida em um plano de "universalidade relativa": a medida, inicialmente entendida como as percepções de cada um, passa a ser, a partir da ação discursiva, o consenso. Assim, para Protágoras, o logos tem um valor construtivo e unificador, em vez de um valor informativo, e, se aplicado com vistas ao melhor, será terapêutico para a cidade.

Palavras-chave: Protágoras, discurso, homem-medida, democracia, consenso.

Abstract: From the point of view of the sophistic rhetoric the attributes that turn persuasive an argument are independent of the scientific character of the discourse and there is not a universal criterion to the judgment and the formulation of laws. With the lack of an absolute and fixed criterion, Protagoras proposes that the majority chooses what appears to be the best now for the pólis. This places the measure-man in a plan of "relative universality": the measure, initially understood as the perceptions of each one, becomes, starting from the discursive action, the consensus. Therefore, for Protagoras, the logos have a constructive and unifier value, instead of an informative value and if applied with views to the best it will be therapeutic for the city.

Keywords: Protágoras, discourse, measure-man, democracy, consensus.

Do ponto de vista da sofística, os atributos que tornam um logos ( $\lambda$ óyoৎ) persuasivo são independentes da cientificidade desse discurso. O ser é apenas aquilo que se diz que ele é, pois é impossível dizer o que as coisas são. $\mathrm{O}$ logos implica, por si mesmo, a realidade do que ele enuncia, uma vez que as coisas são o que parecem a cada um em cada circunstância. Assim, as coisas não são nada além da representação que se tem delas e a linguagem possui autonomia com relação ao ser em si. O domínio do discurso não pode ser, portanto, o do conhecimento de verdades absolutas, e passa a ser o das relações humanas, com privilégio da ação do discurso sobre a subjetividade do auditório. Nesse sentido, a retórica não se funda na ciência, e seu valor está na eficácia que dá a todas as ciências.

A arte retórica se define, no Górgias, como a capacidade de produção de discursos persuasivos sobre todo e qualquer assunto, o que pressupõe que se aceite a verdade de toda e qualquer proposição. A retórica, pois, é vista como um fazer que se esgota na produção do discurso. É um ato de linguagem, e não um ato que tem a linguagem como instrumento de revelação da objetividade,

${ }^{1}$ Doutora em Filosofia pela Universidade de São Paulo, professora adjunta da Universidade Federal de São Carlos. 
tal como é a dialética socrática. Segundo o Górgias platônico, a oratória tem superioridade sobre o conjunto das artes ( $\mathrm{Grg}$., 456a-457c). Ao disputar com um profissional técnico, o orador persuadirá melhor do que ele porque conhece as técnicas de produção do discurso. $\mathrm{O}$ logos tem um poder universal e, sem a retórica, as técnicas seriam apenas conhecimentos teóricos sem eficácia prática.

Trata-se de saber, então, como medir a eficácia do logos, já que não há um critério universal para a doxa que permita um julgamento sobre o parecer ser. $\mathrm{E}$ aqui recorremos a Protágoras, que foi o primeiro a expor teoricamente esse problema. Minha abordagem de Protágoras será feita a partir de um recorte que envolve trechos de Teeteto, Eutidemo, Crátilo e Protágoras de Platão e excertos de Sexto Empírico e Diógenes Laércio.

O ponto central do pensamento de Protágoras é a tese do homem-medida

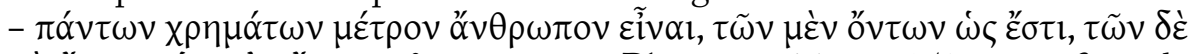

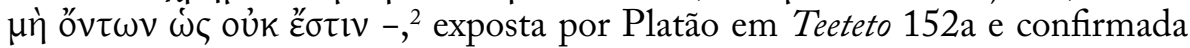
por Sexto Empírico em Contra os matemáticos VII 60:

Alguns incluíram também Protágoras de Abdera entre aqueles filósofos que suprimem o critério [de verdade], pelo fato de que afirma que todas as percepções e as opiniões são verdadeiras, e que a verdade é relativa, porque tudo o que é objeto de parecer e de opinião para alguém, é para ele de modo relativo. Por isso começa seus 'Discursos Destruidores' dizendo que o homem é a medida de todas as coisas, das que são como são e das que não são como não são.

Esse dito de Protágoras tem sido alvo de muitas controvérsias de interpretação. Opto pela interpretação de Untersteiner (1996: 115-128), seguida também por Kerferd (1981): o que é medido sobre as coisas não é sua existência - resultado da tradução de $\omega$ ç como que - mas o modo como elas são ou não são, ou seja, que predicados possuem e que predicados não possuem

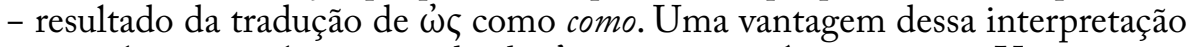
é que ela não exclui o sentido de $\omega$ c como que. Ao contrário, Untersteiner considera que as duas interpretações são complementares, pois existir implica se manifestar de algum modo. A palavra $\mu$ ź

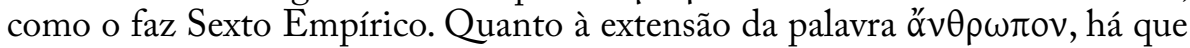
se decidir se se trata de uma singularidade contingente ou do homem universal. Sigo ainda a leitura de Untersteiner, segundo a qual há uma dupla extensão do conceito: o homem individual e o homem universal são dois sentidos complementares de um mesmo processo.

A partir dessa interpretação do escopo do homem-medida, teremos, então, na apresentação que Platão faz de Protágoras no Teeteto, dois momentos: um momento destrutivo do critério de verdade, em que o homem-medida é entendido como o homem particular, e um momento construtivo, que apresenta o logos como unificador do critério.

\footnotetext{
${ }^{2}$ O homem é a medida de todas as coisas, das que são como são e das que não são como não são.
} 
No primeiro momento da apresentação da tese, a medida medirá aquilo que está sendo agora. Há, aqui, um esvaziamento do conceito de ser em si e o estabelecimento de um relativismo do conhecimento e dos valores, que impede a determinação de um critério de verdade, pois todas as opiniões possuem o mesmo valor. Esse momento pode ser reconhecido na explicitação que Platão

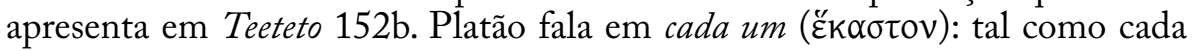
um percebe as coisas é como elas são para essa pessoa. E explica isso por meio de um exemplo: às vezes acontece que, o mesmo vento soprando, uma pessoa o sente frio e outra não, uma o sente moderadamente frio, outra fortemente. Essa afirmação é apresentada em oposição a dizer que o vento em si é frio ou não-frio. Se fosse esse o caso, um dos percipientes estaria certo e outro estaria errado, pois a medida da afirmação o vento é frio e da negação $o$ vento não é frio seria o próprio vento. Mas, para Protágoras, o vento não é em si nem quente nem frio; ele é o que parece para cada um, vento frio para mim e vento não frio para você. Ser, portanto, é parecer. Isso fica mais claro em Crátilo 385e-386e, onde a doutrina do homem-medida é associada à tese de

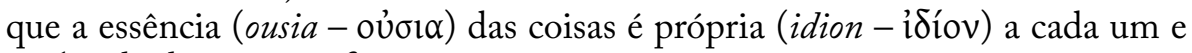
explicada da seguinte forma: na prática são para mim como parecem a mim e para você como parecem a você.

Em Teeteto 152c, é estabelecida uma equivalência entre perceber e parecer. Assim, o vento é frio para quem o sentiu frio, pois é dessa maneira que ele aparece a quem sentiu assim. Logo, aparência e percepção se equivalem. E a percepção é sempre percepção do que é,e, desse modo, é sempre verdadeira. Cada percepção individual para cada pessoa e em cada ocasião não pode ser corrigida. No plano das aparências, a percepção ganha o estatuto de "conhecimento", pois tanto a percepção quanto o conhecimento são sempre verdadeiros. No entanto, conhecimento, aqui, está longe de ser a compreensão do conteúdo de algo determinado, já que as coisas não possuem uma ousia constante, e se restringe, em um primeiro exame, à multiplicidade de percepções individuais.

Segundo Platão, a tese de Protágoras só se justifica se compreendida a partir da teoria heraclitiana do fluxo:

[Protágoras afirma] que nada é um, por si e em si, e nem poderias nomear algo com correção, nem indicar alguma qualidade; mas, se chamares a algo grande, também aparecerá pequeno; se chamares pesado, aparecerá também leve; e assim também todas as coisas, dado que nada é unidade, algo ou qualidade. Partindo da deslocação, do movimento e da mistura umas com as outras, todas as coisas se tornam naquelas que estávamos a dizer; não as chamando corretamente, pois nada nunca é, mas vai-se tornando sempre. E sobre isto todos os sábios, um atrás do outro, exceto Parmênides, devem concordar: Protágoras, Heráclito, Empédocles, e, dentre os poetas, os que estão no topo de cada uma das composições, Epicarmo, na comédia, e Homero, na tragédia, quando diz 'Oceano, origem do deuses, e a mãe Tétis', está a afirmar que todas as coisas nascem do fluxo e do movimento (Tht. $152 \mathrm{~d}-\mathrm{e}){ }^{3}$

\footnotetext{
${ }^{3}$ As citações do Teeteto são feitas com base na tradução de Adriana M. Nogueira (Platão,
} 2005). 
A percepção apresentada como produto de uma reciprocidade momentânea entre dois movimentos, e temos, em vez de objeto e sujeito com ousia própria, uma coisa com certa qualidade (por exemplo, branco) e um sujeito que percebe (por exemplo, o olho que vê), ambos em movimento (Tht. 156d-e):

Não há nada que exista em si (...) pois, é pelo encontro de umas com as outras que todas as coisas de todas as espécies se formam, a partir do movimento. Visto que um é agente e outro paciente, não é sem reservas que se pensa em relação a eles como se fossem um. (...) Nada é unidade em si e por si, mas vem a ser sempre em relação a alguma coisa. (Teeteto 157a)

Nem o percipiente nem o objeto podem existir independentemente um do outro. Se formos rigorosos no uso da linguagem, não se pode sequer falar em agente e paciente, pois em nada há estabilidade e não há possibilidade de que percipiente e objeto sejam alguma coisa definida. O que é é a reciprocidade:

É necessário que, quando eu me tornar percipiente, o seja de alguma coisa, pois é impossível que quem se apercebe não se aperceba de nada. E o outro torna-se doce, amargo ou qualquer outra coisa, para alguém, pois é impossível ser doce, se não for doce para ninguém. (...) Penso que, se somos, só nos resta ser um para o outro. (Tht. 160a-c)

Nem essa reciprocidade possui fixidez, pois a união de agentes e pacientes não dá nascimento ao mesmo produto, mas a produtos diferentes, que são percepções em cada instante. Cada percepção é, pois, uma unidade isolada, instantânea, e entre as percepções há apenas diferença. Não é possível haver, entre as percepções, qualquer marca de identidade como relação; cada uma é idêntica a si mesma no momento em que é e, fora dela, só há o não-ser absoluto. Nem mesmo as percepções de um percipiente possuem identidade umas com as outras, como notamos em Teeteto 159b: Sócrates doente é um todo, em oposição a outro todo, Sócrates com saúde. Sequer a memória remete a algo anteriormente fixado. Cada lembrança é uma percepção que se dá no instante (Tht. 166b).

O mundo, para Protágoras, é como o universo de Funes, o memorioso, de Borges - uma pluralidade infinita de seres isolados, absolutamente distintos. O cachorro das 3 h 14, instantâneo, se dissolve. Tudo o que ele é é o cachorro das 3 h14 e não será o mesmo cachorro às 3 h15. Este, com relação ao primeiro, é o absolutamente outro. Dois cachorros absolutamente idênticos a si mesmos e absolutamente outros que o outro, mas nunca o mesmo cachorro em dois estados diferentes, pois isto exige relativização da identidade, coisa que Funes, quem sabe um bom discípulo de Parmênides e de Protágoras, não pode conceber. Nenhuma coisa que Funes perceba do mundo possui o mínimo traço de uma relação com o outro que permita uma relação no pensamento. Percepções justapostas, lembranças justapostas, isoladas, incapazes de se cruzar - cada mundo é povoado de uma infinidade irracional, irredutível. 
O vento-frio que percebo agora é diferente da percepção de outra pessoa, e diferente também do vento-frio que percebi em outro momento. $\mathrm{O}$ vento-frio é diferente, o percipiente é diferente. O que permanece idêntico é o logos vento-frio. Em cada instante que alguém diz o vento é frio, fala de percepções distintas, embora as palavras sejam as mesmas. Isso permite concluir que, entre as percepções e o que se diz delas, a relação é puramente convencional e que a única fixidez que pode ser considerada é a do próprio logos.

A partir do que foi exposto, pode-se compreender a tese das antilogias, atribuída a Protágoras por Diógenes Laércio (IX,51): "Protágoras foi o primeiro a dizer que em relação a qualquer assunto há duas afirmações contraditórias". Segundo Dupréll (1948: 40), todo logos pode ser afirmado ou negado segundo o ponto de vista em que o consideramos. Não se trata de afirmação e negação de uma mesma realidade. Tampouco se trata da oposição de dois lógoi que remetem, cada um deles, a um ser diferente com determinação própria.

Proponho essa interpretação a partir de Eutidemo 283e-286b, onde Platão expõe argumentos contra a falsidade e contra a contradição, os quais Sócrates atribui a Protágoras ${ }^{4}$ e a outros mais antigos, em referência talvez a Parmênides. Esses argumentos encontram-se divididos em duas grandes linhas, a primeira envolvendo dois argumentos no plano do discurso (Euthd. 283e-286b), a segunda envolvendo dois argumentos no plano do pensamento (Euthd. 286d-287a). Para atingir os objetivos propostos neste trabalho, limitar-me-ei aos dois primeiros argumentos - é impossível dizer falsidade e é impossível contradizer. Entre os pressupostos que sustentam os argumentos, temos que: para cada coisa, há um logos preciso, correspondente a essa coisa; a coisa da qual falamos é um ser uno e separado das outras coisas; não se diz o que é de um modo qualquer, mas como é.

Podemos concluir, no horizonte estabelecido por Protágoras, que o referente do logos é um pragma enquanto fato de percepção. E dado que a percepção é tal como eu a percebo, é verdadeira. Os lógoi dizem o que cada "coisa" é para cada indivíduo tal como é, ou seja, como parece a esse indivíduo. Assim, o logos está em correspondência transitiva com um parecer ser instantâneo. Sobre cada coisa que eu percebo, há um enunciado que diz esta percepção no momento em que a percebo.

A expressão discursiva das sensações não corresponde a uma estrutura sujeito-predicado, mas pode ser entendida como nomeação. Se não há algo como o vento em si, separado de suas qualidades, e se eu só posso perceber o vento frio como uma unidade vento-frio, o enunciado seria o nome complexo de um fato de percepção. Esse fato da percepção é uno e separado por componentes circunstanciais. E, dado que ele é como eu o percebo, é verdadeiro. Desse modo, o enunciado está colado ao ser, como em Parmênides. Não ao ser em si, no entanto, mas ao ser relativo à percepção.

A partir do estabelecimento da relatividade contextual, Protágoras recusa a contradição; porém, diferentemente de Parmênides, o faz sem recusar a

${ }^{4}$ Temos o testemunho de Diógenes Laércio (IX, 50-56), de que Protágoras realmente formulou tais teses. 
negação. Não há contradição entre os enunciados $A$ é $B$ e $A$ não é $B$ porque eles recebem qualificadores do tipo para a e para $b$. Assim, não se pode dizer o que é de um certo modo, afirmando ou negando o mesmo logos referente à mesma coisa em circunstâncias diferentes, já que não se trata da mesma coisa em circunstâncias diferentes, mas de coisas diferentes, pois parecem de modo diferente para pessoas diferentes. Os lógoi dizem o que cada coisa é para cada sujeito tal como ela é, ou seja, como parece a esse sujeito. Falar de uma coisa como ela não me parece equivale a negar o predicado desta coisa neste momento para mim, ou seja, para cada coisa neste momento para mim, há dois lógoi em oposição, que correspondem a falar da coisa como ela me parece e falar da coisa como ela não me parece. Nessa perspectiva, não há como contradizer outra pessoa, porque ela não fala da mesma coisa que eu, senão de como as coisas parecem a elas.

Podemos pensar, no entanto, que, se cada percepção é verdadeira, há muito mais que dois lógoi em oposição sobre cada coisa, dada a multiplicidade das percepções e a relação direta entre logos e parecer ser. Mas a grande variedade de experiências perceptuais pode ser reduzida a dois lógoi: o que afirma uma percepção e o que a nega. Essa interpretação possibilitaria uma análise da negação. O problema da negação é que ela só tem sentido se há um objeto ao qual se refira. Como o enunciado o vento é quente, segundo a teoria dos dois lógoi em oposição, pode ser traduzido para o vento não é frio, a negação teria um referente positivo, ou seja, o não-frio indicaria quente.

A multiplicidade irracional do fluxo é, portanto, dividida em dois pólos pelo logos. A multiplicidade de aparências, quando inserida na linguagem, reduz-se a uma oposição de lógoi coerentes e incomensuráveis. Assim, é possível sustentar, ao mesmo tempo, que $\mathrm{A}$ é $\mathrm{B}$ e não é $\mathrm{B}$, já que dois lógoi $A$ é $B$ e $A$ não $e ́ B$ não são sobre a mesma coisa. $E$ sequer existe "a mesma coisa".

$\mathrm{O}$ sujeito protagoreano parece, pois, ser um indivíduo encerrado em sua subjetividade, cuja medida é incomensurável com a medida de outros indivíduos. Cada indivíduo tem suas próprias experiências subjetivas, que não podem ser transmitidas aos outros. Os sentidos são incapazes de mostrar um mundo unificado (cf. Alcalá, 1994: 124). Esse "sujeito" isolado, no entanto, não é um sujeito determinado, um sujeito substancial que descobre o mundo, que conhece seus objetos. Não se pode falar em objetos em si na filosofia de Protágoras, muito menos em sujeito em si. Nesse primeiro momento da compreensão da doutrina do homem-medida, "sujeito" e "objeto" só existem em reciprocidade, no fluxo. Não há identidade permanente, nem auto-determinação, nem si-mesmo; há um "eu" a cada momento.

Talvez possamos ver em Protágoras um certo relativismo subjetivista que envolve uma dose de ceticismo no que se refere ao conhecimento. Só existem verdades subjetivas relativas ao "sujeito" que as tem. Mas essas verdades não provêem exclusivamente das aparências percebidas, não dependem só das coisas, mas dependem do estado subjetivo de cada um, que varia de um homem a outro e de uma circunstância a outra. Assim, o percebido não é algo em si, um "objeto" a espera de ser encontrado por um "sujeito". Tampouco 
é livre da percepção e, nem sequer, constituído pela percepção. O que cada coisa é, ela é para quem a percebe, ela é inseparável da percepção. Ela não é um ser em si que, com a chegada de um observador, passa a ser conhecida. A percepção não é uma primeira descoberta do objeto, antecedendo seu conhecimento propriamente dito. Ela corresponde a toda apreensão possível do mundo. A fantasia (phantasía), em vez de mera aparência, é um fenômeno organicamente verdadeiro para quem o percebe.

Temos aqui, no entanto, um problema, que não passou despercebido para Platão. Cada homem difere do outro ao infinito (Tht. 166d); eles têm, entre eles, um abismo não dizível. Assim, o caráter inicial da percepção é o de uma espécie de átomo ontológico, incomensurável com outras percepções, com outros átomos ontológicos. O destino desses átomos ontológicos, traçado pelo dito de Parmênides "é o mesmo pensar e ser", seria sua expressão em átomos lógicos incomunicáveis aos outros, mas, mais perturbador ainda, incompreensíveis para a mesma pessoa. A prescrição de Parmênides obrigaria a uma espécie de linguagem privada para cada instante de cada percepção. Esse problema é talvez superado quando Platão apresenta, em Teeteto 166a-168c, o que seria o segundo momento da tese do homem-medida, o momento reconstrutivo.

Ao homem-medida cabe superar a ontologia do fluxo e construir, com o logos, um mundo com sentido. Cada percepção, em cada momento, é diferente das outras e o que permanece idêntico é o nome, fruto da convenção. Assim, o logos garante um significado convencional para as coisas em fluxo. O ser não se aplica fora dos limites do fluxo, mas é resultado de uma fixação transitória. É o logos que funda o ser.

O ser, para Protágoras, seria a expressão de um recorte do devir, que se fixa temporariamente segundo a adesão da maioria. Não é possível, pois, pensar que seja função do logos transmitir conhecimento objetivo. $\mathrm{O}$ logos pertence ao âmbito da ação. Dentro dessas margens, o conhecimento não será compartilhado, mesmo porque não haverá um conhecimento que seja alcançado por todos. As relações humanas só se tornam possíveis através do consenso.

É esse papel do logos que nos permite reconhecer um segundo sentido na doutrina do homem-medida, que deixa de ser cada homem para fundar o critério na maioria. Se os lógoi de cada homem equivalem em termos de verdade, eles diferem quanto ao seu uso. Segue-se então uma reconstrução do padrão de verdade, definido agora pela utilidade, como vemos em Teeteto $166 \mathrm{~d}-167$ c, passagem que corresponde à defesa que Protágoras faria de sua teoria, em resposta à questão formulada anteriormente por Sócrates - se cada homem é a medida de seus próprios juízos, como pode Protágoras dizer que é mais sábio que os demais? Diria Protágoras:

Afirmo que a verdade é como a escrevi. Pois cada um de nós é a medida do que é e do que não é, e no entanto cada um difere infinitamente do outro: para um é uma coisa e assim aparece, a outro é e aparece outra coisa. E estou longe de negar que exista a sabedoria e o homem sábio. Mas este mesmo a quem chamo sábio é aquele de nós que, quando as coisas são e lhe aparecem más, as muda, de 
modo a aparecerem e serem boas. (...) Para quem está doente, aquilo que come aparece e é amargo, mas para quem está saudável aparece e é o contrário. E não é preciso fazer mais sábio nenhum dos dois - pois não é possível -, nem se deve acusar o doente de ser ignorante por ter esta opinião, nem o saudável de sábio por ter outra; mas deve-se fazer uma mudança no doente, porque é melhor o estado do outro. Do mesmo modo, também na educação se deve fazer uma mudança de um estado para outro melhor; mas o médico faz a mudança com remédios e o sofista com discursos. Por conseguinte, não fez com que o que tem uma opinião falsa tivesse posteriormente uma opinião verdadeira; pois não é possível ter opinião sobre o que não é, nem ser afetado por outra coisa que não aquela que o afeta, que será sempre verdade. Mas penso que, a quem tem uma opinião afim ao defeituoso estado de alma em que se acha, um benéfico estado de alma fará ter outras opiniões como esta, imagens a que alguns, por ignorância, chamam verdadeiras; eu chamo a umas melhores que as outras, mas não mais verdadeiras. (...) E afirmo que os oradores sábios e bons fazem com que as coisas benéficas pareçam ser justas às cidades, em vez de defeituosas. Pois aquilo que a cada cidade parece justo e belo é isso para ela, enquanto assim a determinar.

Protágoras propõe a substituição do critério de verdade por um critério prático - o que parece melhor. Isto significa que uma coisa ou ação pode ser boa para uma pessoa e ruim para outra e, mais do que isto, pode ser boa e ruim para a mesma pessoa em circunstâncias diferentes, na medida em que esta pessoa acredite assim. Pela ação do logos, aquilo que parece bom pode passar a parecer ruim, e o que parece ruim pode passar a parecer bom. Verdadeiro e falso dão lugar para o melhor e o pior. Esse par está em devir, não se cristaliza no tempo, muda no instante em que muda a opinião da maioria. $\mathrm{O}$ consenso imprime uma permanência relativa ao fluxo - permanência enquanto durar o consenso.

Embora o conteúdo do logos tenha uma fixidez relativa, a capacidade de transformar e reunir percepções pelo logos será absoluta. Protágoras não pretende que o discurso diga a verdade, mas que modifique o comportamento de alguém, tornando-o melhor. A escolha de um logos em detrimento de seu contrário não é a opção por um enunciado objetivamente verdadeiro, aquele que diz o que a coisa é, mas a opção por um enunciado mais útil do ponto de vista da ação.

A "verdade" pode ser entendida não como um dado inicial que remete ao ser em si, mas como valor constituído através da adesão da maioria dos ouvintes a certos juízos que são instituídos como norma: cada sujeito escolhe aquilo que lhe parece melhor, e o que parece ser melhor para a maioria passa a ser regra. O campo veritativo deixa de ser, portanto, o campo das inesgotáveis opiniões subjetivas. $\mathrm{O}$ logos instaura uma certa objetividade à verdade, enquanto ação convergente de muitos sujeitos por meio do consenso. Todas as percepções subjetivamente verdadeiras convergem para uma única percepção que é não a mais verdadeira, mas a melhor, e que passa a ser tomada como "objetivamente verdadeira" quando aceita pela maioria, enquanto for aceita. A verdade, portanto, é reversível. 
A verdade estaria na convergência de opiniões, não remetendo ao ser anterior ao logos, mas ao "ser" produzido a partir do logos, na medida em que se assegure as condições de adesão dos ouvintes a esse discurso.

A maioria é o critério regulador do melhor e do dever ser: a opinião particular verifica-se pelo seu acordo com a opinião aceita pela maioria. $\mathrm{O}$ discurso do sábio é o melhor porque a maioria o considera assim. $\mathrm{O}$ sábio, portanto, caracteriza-se como aquele que sabe fazer triunfar uma opinião que tem mais valor, sendo que os juízos de valor estão submetidos aos critérios de coerência e eficácia.

Pode-se falar, então, em racionalidade como capacidade de mudar as percepções de outras pessoas e aceitar mudanças em suas próprias percepções, pela adesão ao logos do outro, tendo em vista o que parece ser melhor no âmbito da ação. A racionalidade é vinculada à ação política, expressando-se, na pólis, como fazer parecer justas às cidades as coisas boas em substituição às más (Tht. 167e). Assim, o homem é a medida de todas as coisas, e não o porco ou qualquer outro animal que tenha percepção (Tht. 161b, 166c), porque só o homem pode, por meio do discurso, mudar a percepção. E se o faz tendo em vista o melhor, pode ser chamado de sábio, prudente e zeloso da virtude (Tht. $166 c-d)$. O sábio indica aos homens o melhor caminho pelo uso da razão, entendida como faculdade de aperfeiçoamento do logos. No plano da ação, Protágoras propõe uma distinção entre o disputador e o dialético. O primeiro busca lograr o adversário; o segundo esforça-se para mostrar ao interlocutor os erros nos quais incorreu (Tht.167e), e este é o sábio.

As noções de logro e erro presentes aqui parecem, em um primeiro exame, incompatíveis com a tese de que todos os enunciados são verdadeiros. Mas podemos pensar em engano e erro não com referência a uma verdade objetiva, mas com referência à "verdade" consensual. Nesse sentido, engano e erro podem ser entendidos como ir contra a decisão da maioria.

A adesão, não ao que é verdadeiro em oposição ao falso, mas ao que parece melhor para a maioria, coloca o homem-medida em um plano de "universalidade relativa": a medida, inicialmente entendida como as percepções de cada um, passa a ser, a partir da ação discursiva, o consenso. Assim, podemos dizer que o logos tem um valor construtivo, em vez de um valor informativo. Tal valor construtivo, se aplicado com vistas ao melhor, será terapêutico para a cidade.

No diálogo Protágoras (318e-328d), Platão faz uma exposição do modo como esse sofista entende a democracia e os valores nela envolvidos, como a justiça e a virtude. Embora o Protágoras apresente o pensamento protagoreano em alguns pontos distinto daquele exposto no Teeteto, não será difícil percebermos certa unidade entre eles, principalmente no que tange à compreensão do logos como um modo de fixar o fluxo, embora temporariamente, e permitir a ação política.

A discussão central sobre esse tema tem início com uma afirmação, do personagem Sócrates, que põe em questão a função sofística: a virtude não pode ser ensinada e, portanto, não há nenhuma fundamentação para a pretensão de Protágoras em ser um mestre de virtude política. Para sustentar sua tese, 
Sócrates apresenta duas razões (Prt.319a-320c). Em primeiro lugar, quando se trata de questões técnicas, os atenienses recorrem a especialistas; mas quando se trata da administração da cidade, qualquer pessoa pode dar opinião. Assim, a política não se constitui como uma técnica e seus valores não podem ser transmitidos. Além disso, os mais sábios e melhores cidadãos, como Péricles, não são capazes de transmitir a virtude para seus filhos. Temos, portanto, um duplo problema para Protágoras: se a virtude não pode ser ensinada, a profissão de Protágoras é uma fraude; mas se a virtude pode ser ensinada, Péricles não conhece a natureza da virtude política.

Protágoras responde ao questionamento de Sócrates, inicialmente, em forma do mito de Prometeu e Epimeteu (Prt. 320c-322d). Epimeteu distribuiu os vários poderes entre os animais segundo um princípio igualador, mas, por um descuido na distribuição, os homens não receberam poderes e ficaram desprotegidos. Por isso, Prometeu roubou para eles o fogo e a habilidade artesanal. Para se defenderem, os homens fundam cidades, mas como lhes faltava a arte da política, a injustiça os impediu de viverem juntos. Por isso, Zeus enviou Hermes para dar aos homens respeito de si e justiça. Assim, as artes foram distribuídas de modo diferente entre os homens, mas a justiça e o respeito de si são dados de modo igual. Essa participação na justiça e na virtude política não é por natureza, mas é adquirida pela instrução e pela prática. Após essa conclusão, Protágoras oferece uma nova resposta às críticas de Sócrates, agora em forma de logos (Prt. 324d-328d), afirmando que o ensino da virtude é universal através da comunidade. E, já que as pessoas têm aptidões naturais diferentes, algumas pessoas aprendem melhor do que as outras, e algumas ensinam melhor do que as outras. Os homens virtuosos se empenham por transmitir a virtude a seus filhos. Se eles não conseguem, as falhas são relativas, pois é isso o que acontece em todas as artes.

Nota-se que o escopo da política, para Protágoras, não é o da competência técnica, fundada na desigualdade, mas o da competência do logos, fundado sobre a igualdade. Será tarefa da educação oferecida pelos sofistas guiar os homens em busca de opiniões que pareçam ser melhores. Sobre estes pressupostos, haverá, em Protágoras, a elaboração de dois tipos de discursos: o discurso forte em contraposição ao discurso fraco. Segundo Romeyer-Dherbey (1986: 26), o discurso forte seria aquele aceito pela maioria das pessoas, enquanto o discurso fraco se constituiria no discurso não compartilhado.

Todos os cidadãos podem possuir a virtude política. Desse modo, pode se constituir, na pólis, se não um discurso unânime, ao menos um discurso majoritário, que representa o discurso forte, cuja força está no consenso. Não havendo um critério absoluto e fixo, o logos escolhido será aquele que aparece como melhor, agora, para a pólis. O critério, então, será o poder de comunicação do logos, ou seja, o poder que ele tem de se impor à maioria, de mudar percepções em vista do melhor.

Se não há, em Protágoras, uma verdade adequada ao mundo, mas verdades relativas a "cada mundo", não há nenhuma possibilidade de certeza da 
adequação da verdade ao sentido, e logos não indica um significado prévio, mas a possibilidade de construir significados. Para Protágoras, aprender a virtude não é buscar o que já está dado. É, antes de tudo, aderir ao que parece melhor para a maioria, sendo que nessa adesão já está presente a possibilidade de uma transformação. $\mathrm{O}$ homem que muda sua percepção para aderir ao consenso é o homem que pode mudar esse consenso. Aderir e mudar são, ambos, expressões do logos.

O logos permite que a decisão política seja discutida e revertida. A multiplicidade de opiniões, assim como a multiplicidade de percepções, não conduzà irracionalidade. $\mathrm{O}$ logos, portanto, permite organizar toda a multiplicidade possível em dois pólos opostos. Destes dois pólos, dois lógoi em oposição, um será fraco e outro será forte; um será pior e outro melhor. A adesão ao melhor estabelece a delimitação do campo veritativo.

Entre a multiplicidade irracional e a unidade incomunicável, entre o fluxo e a eterna fixidez, Protágoras propõe uma terceira via - a do consenso e da reversibilidade. É o acordo sobre o que deve ser que torna o mundo racional.

A racionalidade protagoreana não implica o abandono da percepção. Ela segue um outro caminho, segundo o qual o homem está intimamente envolvido no mundo que percebe e no qual age. Para Protágoras, o logos não é exterior à percepção. Ele representa o próprio caráter dinâmico de nossa maneira de apreender e agir no mundo. O logos é a condição da percepção humana que representa possibilidade de ação, restitui ao homem-medida a inteligibilidade do que ele é e do que ele faz. Nesse sentido, o logos unifica o mundo.

\section{Bibliografia}

Alcalá,J. R.(1994). El escepticismo antiguo:posibilidad del conocimiento y buisqueda de la felicidad. Córdoba: Universidad de Córdoba.

Borges, J. L. (1989). Funes, el memorioso. in Borges, J. L. Obras Completas. Buenos Aires: Emecé Editores.

Cassin, B. (ed.). (1986). Positions de la sophistique. Paris: Vrin.

Diogenes Laercio. Vie, Doctrines et Sentences des Philosophes Illustres. Tradução de R. Genaille. Paris: Garnier-Flammarion, 1965.

Diôgenes Laêrtios. (2008). Vidas e doutrinas dos filósofos ilustres. Tradução do grego, introdução e notas de Mário da Gama Kury. 2 ed., reimpressão. Brasília: Editora Universidade de Brasília.

Dupréel, E. (1948). Les sophistes: Protagoras, Gorgias, Prodicus, Hippias. Neuchatel: Éditions du Griffon.

Guthrie, W. K. C. (1971). The sophists. London: Cambridge University Press.

Jaeger, W. (2001). Paidéia. Tradução de Artur M. Parreira. São Paulo: Martins Fontes. 
Kerferd, G. B. (1981). The Sophistic Movement. Cambridge: Cambridge University Press.

Pantel, P. S. (dir.). (1991). L'Histoire des femmes, L'Antiquité. Paris: Plon.

Pinto, M. J. V. (2000). A doutrina do logos na sofística. Lisboa: Colibri.

Platão. Teeteto. (2005). Tradução de Adriana Manuela Nogueira. Lisboa: Fundação Calouste Gulbenkian.

Plato. Cratylus. (1996). Tradução de H. N. Fowler. Cambridge-London: Loeb Classical Library.

Plato. Euthydemus. (1996). Tradução de W. R. M. Lamb. Cambridge-London: Loeb Classical Library.

Plato. Protagoras. (1996). Tradução de W. R. M. Lamb. Cambridge-London: Loeb Classical Library.

Plato. Theaetetus. (1996). Tradução de H. N. Fowler. Cambridge-London: Loeb Classical Library.

Romeyer-Dherbey, G. (1999). Os sofistas. Tradução de J. Amado. Lisboa: Ed. 70.

Sexto Empírico. Against the Logicians. Tradução de R. G. Bury. Cambridge: Loeb Classical Library, 1983.

Untersteiner, M. (1996). I sofisti. Milão: Bruno Mondadori.

Wolff, F. (1983). Filosofia grega e democracia. Discurso, Revista do Departamento de Filosofia da FFLCH/USP, São Paulo, n. 14, 7-49. 